CASA NOVA, Vera; VAZ, Paulo Bernardo. (Org.). Estação Imagem: desafios. Belo Horizonte: Ed. UFMG, 2002. 214 p. (Humanitas)

\title{
Imagens: fronteiras, limites, transgressões
}

Ram Avraham Mandil I UFMG

Não farás para ti imagem de escultura, nem figura alguma do que há em cima no céu e do que há em baixo na terra, nem do que há nas águas debaixo da terra. Não adorarás tais coisas, nem lhes prestarás culto.

Êxodo, 20.

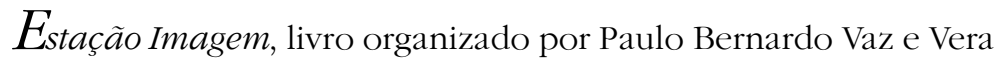
Casa Nova, nos mostra a distância que nos separa do mandamento divino endereçado ao povo do Livro. As imagens estão por toda parte, trafegando pelos céus, encravadas em cada pedaço de chão ou à deriva neste oceano de signos no qual estamos imersos.

Através de uma edição bem cuidada, que inclui uma seleção de imagens de desenhos de Francis Picabia e Antonin Artaud, além de uma impressionante foto do túmulo de Jorge Luis Borges, Estação Imagem propõe um duplo desafio: um desafio próprio da imagem, associada aqui ao signo, como tudo aquilo que ele mobiliza de enigmático em seus deslocamentos e insinuações; e um desafio próprio do livro, que é o de procurar fazer uma circunavegação da imagem através do fluxo de diferentes abordagens de "análise dos signos", que seriam, em última análise, modos distintos de apropriação da imagem. 
A perspectiva dos organizadores parte de uma equivalência entre a imagem e o signo, a imagem convertida, portanto, em "texto a ser lido". Nesse sentido, trata-se de abordar a imagem já com um valor significante, sob a incidência, portanto, da ordem simbólica. Pode-se inferir daí um outro desafio, aludido por alguns dos textos dessa coletânea, que seria o de pensar a imagem descolada da significação, o que talvez obrigasse considerá-la a partir do que oferece resistência à representação.

Vivemos, é verdade, sob o "império dos signos", não mais restrito ao Japão visitado por Barthes. Lacan preferiu designar esse império como o "império dos semblantes" em que o encadeamento de imagens e de símbolos funcionaria como tela diante dos limites ao que, da realidade, resiste à representação. Nesse aspecto, Estação Imagem é uma parada obrigatória nesta viagem ao mesmo tempo epistêmica e iconográfica que nos conduz até os confins desse império.

O roteiro-guia procura responder aos desafios que o livro propõe a partir do diálogo entre as artes. Nada mais apropriado, se consideramos as artes como lugar privilegiado de criação, proliferação, manipulação e transporte de imagens. Trata-se de um diálogo mobilizado a partir de múltiplos ângulos e o livro contorna muito bem os riscos de uma cacofonia.

Encontramos aí, entre outras, a noção de correspondência entre as obras de arte, extraída de Malraux, ou o desenvolvimento da noção de "nomadismo paradoxal" como modo privilegiado de intertextualidade entre campos distintos da arte. É no exercício de aproximação e de tensionamento de forças que compõem o universo da arte que o livro mostra a sua exuberância.

No livro estão presentes estudos relevantes, por exemplo, sobre a presença da escrita nas obras de arte e sobre as imagens mobilizadas pelas palavras e letras quando abordadas em sua dimensão de objeto, para além, portanto, de sua função comunicativa. A partir dos desenhos de Picabia, encontramos um instigante estudo a respeito da fragmentação e desarticulação da linguagem pictórica ou textual através da intermediação da máquina. Num olhar de filatelista dirigido para os desenhos/ "objetos falantes" de Artaud, nos deparamos com uma aproximação singular entre o poema e o desenho, em que o visível não se confunde com o legível.

Dois interessantes artigos abordam a relação entre pintura e literatura. Um primeiro estudo recupera, na história, o rompimento de hierarquia entre elas, o que dará a possibilidade de surgimento da figura do "artista". Um 
outro trabalho parte de uma hipótese instigante: a filiação do modernismo na literatura brasileira deve ser buscada mais no "intertexto extraliterário" do que na tradição literária. Aqui a demonstração vai mais longe, ao se compor uma analogia de estrutura entre imagem narrativa e pictórica na action painting de Pollock e uma eventual action telling mobilizada por Guimarães Rosa em "Meu tio, o iauaretê".

A aproximação entre literatura, cinema e vídeo também se faz presente. De um lado, um cuidadoso estudo sobre o efeito de "atopia" detectado no deslizamento entre a página em branco e a tela de cinema na obra de Marguerite Duras. De outro, a dança com a câmera de um Glauber Rocha vídeo-artista, produtor de uma "imagem da resistência" (o que poderia ser confrontado com as resistências da imagem).

A circulação contemporânea das imagens merece dois lúcidos artigos que procuram iluminar a passagem da estrutura analógica para o regime do digital. Tal passagem estaria comprometida com os efeitos de hiper-realidade, com o deslocamento da questão entre aparência/verdade para a dinâmica do atual/virtual. Seríamos contemporâneos da inauguração de um novo regime do visível a partir de uma deriva sem precedentes da imagem.

Nesse itinerário poderíamos acrescentar, aos desafios propostos pelo livro, aqueles implicados na relação ao corpo como imagem, seja através de uma referência cada vez mais direta ao corpo nas explorações artísticas da arte contemporânea, seja no universo das imagens corporais que hoje nos fazem crer que habitamos um "corpo transparente".

De qualquer modo, é preciso constatar que dificilmente saímos da Estação Imagem da mesma forma que chegamos a ela. Trata-se de um livro que certamente se tornará uma "estação de baldeação" obrigatória para os estudos contemporâneos sobre a relação entre as imagens e as artes.

Trata-se de um território que anuncia, desde o mandamento divino, que estamos numa fronteira entre o sagrado e o profano, entre o limite e a transgressão, entre o prazer e o gozo, atravessado, aqui, pelos trilhos dessa investigação.

E tem-se tornado cada vez mais necessário embarcar nessa viagem. 